\title{
Differentiation and characterization of burrows of two species of armadillos in the Brazilian Cerrado
}

\author{
Roberto Guilherme Trovati
}

\begin{abstract}
Background: Signs left by some mammals such as tracks, trails, burrows, scratches, feces, hair, and others can be an important tool for species identification. This study was conducted in the Itirapina Ecological Station, in the southern Brazilian Cerrado, whose main objectives were to (1) compare the burrow morphometric variables of Cabassous unicinctus and Euphractus sexcinctus and (2) check for differences in the occurrence of foraging burrows in two different environments: areas with vegetation (shrubby grassland) and areas without vegetation (roads). The collected measures of armadillo's burrows have been width, height, depth, and angle relative to the soil. To record foraging burrows $(<70 \mathrm{~cm})$, the linear transect methodology was used simultaneously in roads and shrubby grassland environments.

Results: In a shrubby grassland environment of the Itirapina Ecological Station, a density of 121 burrows/ha pertaining to C. unicinctus and of 277 to E. sexcinctus was observed. Although there is overlap between them, morphometric variables were used to measure the burrows; significant differences were observed in all: depth, $p<0.001$; ratio, $p<0.001$; perimeter of the ellipse (perimeter), $p<0.001$; and angle of excavation relative to the soil, $p<0.001$. There was an observed interaction between the variables $p<0.001$ for Wilk test. The PCA analysis evidenced two highly distinct groups of burrows, which corresponded to the initial visual classification. The variance explained by axes 1 and 2 was $83.18 \%$. The variable that most influenced the distinction of the burrows of the species was the perimeter. There was a density of 114 foraging burrows/ha across the roads and 42 in shrubby grassland. The results of the ANOVA, $p<0.05$, and Tukey test, $p<0.05$, demonstrate significant difference between the mean densities of foraging burrows in the said environments. This indicates that armadillos use the area devoid of vegetation to feed.
\end{abstract}

Conclusions: Thus, this study provides information that can assist in the surveys of these species as well as to clarify aspects of its ecology in the Cerrado.

Keywords: Burrows, Cabassous unicinctus, Cingulata, Dasypodidae, Euphractus sexcinctus, Xenarthra

\section{Background}

Medium and large mammals found in the Cerrado (Brazilian Savanna) generally have a wide geographical distribution, and they are recorded commonly in other biomes. This fact is observed for most species of the order Cingulata, family Dasypodidae (Fonseca et al. 1996) that in the Cerrado are represented by five genera and eight species of the ten that are found in Brazil. These species are Cabassous tatouay, Cabassous

Correspondence: rgtrovati@yahoo.com.br

Animal Ecology Laboratory, Luiz de Queiroz College of Agriculture (ESALQ), University of São Paulo (USP), Piracicaba, SP, Brazil unicinctus, Dasypus novemcinctus, Dasypus septemcinctus, Euphractus sexcinctus, Priodontes maximus, Tolypeutes matacus, and Tolypeutes tricinctus (Redford 1994; Marinho-Filho et al. 2002; Medri et al. 2011). Apparently, species distribution and abundance within this biome are associated with phytophysiognomical formations and soil characteristics (Anacleto et al. 2006).

Armadillos in general have been studied in the Cerrado since the decade of 1980 (Carter and Encarnação 1983; Encarnação 1987). Nevertheless, there are gaps despite the biology and ecology of the species in the biome. According to Abba et al. (2007), the lack of attention given to the 
Cingulata order is due to the fact that these species are not charismatic. This occurs even regarding species classified globally as "vulnerable" (P. maximus and T. tricinctus) in the IUCN Red List of Threatened Species (Abba and Superina 2010). Thus, the field research on armadillos should be intensified to increase knowledge and conservation (Superina et al. 2014).

Armadillos, like most neotropical species, are rarely observed in nature. However, during their various activities, these species often leave characteristic signs in the environment: trails, burrows, and feces (Brito et al. 2001). Becker and Dalponte (1999) reported that when these signs are interpreted correctly, they can provide reliable identification of the species and also may reveal ecological features such as the following: habitat use, food habits, activities performed, and relative abundance. Animals of the genera Cabassous, Euphractus, Priodontes, and Tolypeutes are associated with drier and higher environments within the Cerrado (Redford 1985), whereas Dasypus sp. shows a preference for more humid sites (Schaller 1983), riparian forests, and footpaths. According to Arteaga and Venticique (2008), in the Brazilian Central Amazon, armadillos prefer to build their nests in areas of low elevation, such that topography is one piece of information that should be considered when evaluating habitat use and estimates of species density. Another important fact observed in this region is that armadillos use areas of primary vegetation more intensively (Arteaga and Venticique 2012).

Species belonging to the genera Cabassous, Dasypus, Euphractus, and Priodontes are efficient diggers. In contrast, Tolypeutes do not dig burrows, rather of this, use the burrows dug by other animals (Medri et al. 2011). The ability of armadillos to dig burrows is directly related with the construction of shelter (housing, raising offspring), protection (escape from predators), and feed (foraging burrows) (Redford 1985; McDonough and Loughry 2003; Bagagli et al. 2004). The species that dig their own burrows produce ones with peculiar shapes and sizes (Srbek-Araujo et al. 2009; Ceresoli and Fernandez-Duque 2012), a fact that is related to the anatomical differences (present in the osteology, muscle, and myology) (Vizcaíno et al. 1999; Koneval 2003) and morphological characteristics (weight, size, carapace format and members) of these animals (Marinho-Filho et al. 1998; Medri et al. 2011).

Bonato et al. (2008) recorded in the Itirapina Ecological Station (Estação Ecológica de Itirapina (EEI)) four species of armadillos: C. unicinctus, D. novemcinctus, $D$. septemcinctus, and $E$. sexcinctus. They observed that the Dasypus occur at a low population density. The same was also seen for the density burrows of this genera in a pilot study (Trovati personal communication) because Dasypus dig burrows with a triangular entrance
(Anacleto and Diniz Filho 2008). The two most common species of armadillos in EEI C. unicinctus and E. sexcinctus may present total length (head, body, and tail similar - $64 \mathrm{~cm}$ ) (Eisenberg and Redford 1999; Nowak 1999). However, on average, the first are smaller and lighter than the second (Redford and Wetzel 1985; Hayssen 2014). The differences between species are kept in many other morphological and anatomical features that appear related to burrowing, as previously mentioned. Other differences are in the diet, E. sexcinctus is omnivorous, feeding on vegetal material (plants, roots and fruits, invertebrates, vertebrates, and carrion (Dalponte and Tavares-Filho 2004; Vaz et al. 2012). While C. unicinctus is insectivorous, the diet of these consists of more than $90 \%$ arthropods (chiefly ants and termites) (Bonato et al. 2008), but acarina and isoptera are also found (Anacleto 2007).

Based on the introductory context that was thought in the following hypothesis, the burrows of armadillos have different morphometrics and that the two species of armadillos here studied, as well as some carnivores, use the roads to get food. So this study has two objectives. The first was to compare the burrow morphometric variables of $C$. unicinctus and E. sexcinctus. The second was to determine whether foraging burrows occur more frequently in areas with vegetation (shrubby grassland) or in areas without vegetation (roads).

\section{Methods}

Study site

The Itirapina Ecological Station belongs to the geomorphological unit of the "Cuesta Basalt Province," which is inserted in a region called the Plateau of São Carlos, wherein the altitude ranges from 705 to $750 \mathrm{~m}$. This is located in São Paulo State, between the municipalities of Itirapina and Brotas at $22^{\circ} 00^{\prime}$ to $22^{\circ} 15^{\prime} \mathrm{S}$ and $47^{\circ} 45^{\prime}$ to $48^{\circ} 00^{\prime} \mathrm{W}$ (Motta-Junior et al. 2008; Trovati and Munerato 2013).

The EEI is a fragment of approximately 2.400 ha of the Cerrado, inserted in an array of areas of cultivated Pinus spp. (pine), Eucalyptus spp. (eucalyptus), Saccharum officinarun (sugarcane), Citrus aurantium (orange), and areas of exotic grassland (predominating Brachiaria decumbens) (Trovati and Munerato 2013). The principal physiognomies of this fragment are the following: 1.250 ha of shrubby grassland (campo sujo) and 370 ha of shrubby grassland with trees (campo cerrado). The landscape is also composed of flood plains and fragments of woody savanna (cerrado sensu stricto), gallery forests, swamp forest, and forest-like savanna (cerradão). Besides the native physiognomies mentioned, there are two areas in which Pinus sp. is cultivated and savannah vegetation native to the Cerrado is currently in the phase of regeneration. A third area of approximately 25 ha is 
still used for Pinus spp. silviculture. Moreover, Pinus spp., Eucalyptus spp., B. decumbens, and Melinis minutiflora are invasive species in virtually all the EEI environments (Trovati 2009). The soil of the drier interfluves is primarily composed of sand (over $85 \%$ ); soils in wetter areas contain $60-70 \%$ of clay or silt (Brasileiro et al. 2005).

\section{Sample area}

Sampling was conducted in an area that included shrubby grassland and the roads that cut through this environment. The soil in both road and shrubby grassland environments sampled showed similar compaction characteristics and the same composition (sand over $85 \%$ ). This area was chosen because it is the predominant physiognomy in the EEI, and according to Redford (1985), the species studied (C. unicinctus and E. sexcinctus) prefer the open, dry areas of the Cerrado. Shrubby grassland areas present a cover that is predominantly composed of grasses interspersed with sparse shrubs, typical country species, and a few individual small tree species. Among the shrubs, Annona crassiflora (marolo), Annona coriacea (araticum-liso), Annona dioica (Marolorasteiro), Campomanesia pubescens (guabiroba), and Caryocar brasiliense (pequi) stand out, which according to Paulino-Neto (2014) constitute an important food resource to fauna, while among the small tree species, Jacaranda caroba and the palm trees Attalea geraensis (Indaiá-rasteiro) and Syagrus petraea (coco-de-vasoura) are worth highlighting.

\section{Sampling and burrow morphometric variables}

The sampling was performed using the linear transect methodology, with each one measuring $3 \mathrm{~m}$ width by $200 \mathrm{~m}$ length $\left(600 \mathrm{~m}^{2}\right.$ per transect). The area surveyed considered only the roads that cut through the shrubby grassland physiognomy, with 11 sampling sites, in which only recently excavated burrows of C. unicinctus and $E$. sexcinctus were counted. An initial visual classification of the burrows of $C$. unicinctus and E. sexcinctus was performed at each sampling point. This classification of armadillo burrows was based on the description proposed by Carter and Encarnação (1983), who described the burrows of $C$. unicinctus as circular and those of $E$. sexcinctus as an "inverted U" (Fig. 1).

However, visual classification is considered subjective, since its effectiveness is related to the observer's experience (McDonough et al. 2000). Abba et al. (2007) indicated that the dimensions, shape of the burrows, and the observation of some of these being excavated could be a determinant in discriminating the excavator species. Thus, the current belief is that the morphometric characteristics of burrows can assist in making this visual classification less empirical.

Following the initial visual classification, the burrows were measured to determine the following morphological characteristics: depth, largest diameter (LD) or width, smallest diameter (SD) or height, and angle of excavation in relation to the soil. The width and height of the burrow opening were measured using a caliper constructed with $30-\mathrm{cm}$ rulers. The ratio of these diameters (LD/SD) and the perimeter of the ellipse (perimeter) were calculated using the division of the largest diameter by the smallest diameter. To measure the angle of burrow excavation in relation to the soil, an inclinometer was used.

To assess the relationship between foraging burrows in the road and shrubby grassland environments, the linear transect methodology was used. The specific measure of each of linear transects was $600 \mathrm{~m}^{2}$. However, this time, the area surveyed included both the road and shrubby grassland physiognomy; 21 points were haphazardly sampled in each environment totaling 1.26 ha. Again, only recently excavated burrows were counted in order to estimate the density in each environment. In addition, the depth of these burrows was measured. Burrows to a depth of less than $70 \mathrm{~cm}$ were considered foraging burrows because the armadillo species studied

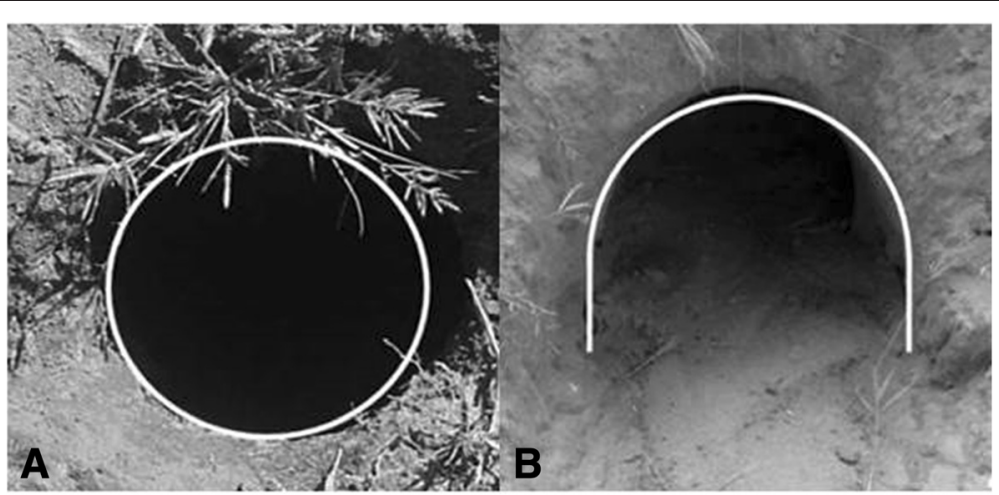

Fig. 1 Burrows of C. unicinctus (a) and E. sexcinctus (b) in the Estação Ecologica de Itirapina 
here generally have the size (length of body and tail) near this measure (Redford and Wetzel 1985; Eisenberg and Redford 1999; Hayssen 2014).

\section{Data analysis}

Comparison between the variables measured, depth, ratio, perimeter, and angle of excavation in relation to the soil, for the burrows of C. unicinctus and E. sexcinctus, was performed by the multivariate analysis of variance (generalized MANOVA). Furthermore, to test the initial visual classification of the burrows, Principal Component Analysis (PCA) was performed using the Multivariate Statistical Package (MVSP) program (Kovach 1999).

Finally, to compare the occurrence of the burrows in the road and shrubby grassland environments, an analysis of variance (ANOVA) was carried out, followed by Tukey test. The generalized MANOVA, ANOVA, and Tukey test were performed using the MINITAB program, version 17.0 (Minitab 2015).

\section{Ethics committee}

Permit to this study were granted by Instituto Brasileiro do Meio Ambiente e dos Recursos Naturais Renováveis (IBAMA 036/2007- CGFAU) and the Instituto Florestal de São Paulo with the research license for the project entitled "Mammals burrowing (Dasypodidae and Echimyidae) Cerrado of Itirapina region and its role in terrestrial vertebrate communities".

\section{Results}

A total of 180 burrows (80 previously classified as pertaining to C. unicinctus and 100 to $E$. sexcinctus) were recorded, with a mean density of 7.27 and 16.63 burrows per transect, corresponding to a density of 121 and 277 burrows/ha to respective species.

Although some degree of overlap occurred among the morphometric variables of burrows of $C$. unicinctus and E. sexcinctus, significant differences were observed for all the variables: depth, $p<0.001$; ratio, $p<0.001$; perimeter, $p<0.001$; and angle of excavation relative to the soil, $p<0.001$ (Table 1). There was an observed interaction between the variables, $p<0.001$ for Wilk test.

The PCA analysis evidenced two highly distinct groups (Fig. 2), which corresponded to the initial visual classification, except for a single $C$. unicinctus burrow, which was classified as E. sexcinctus. The identity of the only burrow misidentified in the initial classification was corrected for all the analysis performed. The variance explained by axes 1 and 2 of the PCA was $83.18 \%$. The variable that most influenced the distinction of the burrows of the species studied here was the perimeter, followed by the variables, ratio, angle of excavation in relation to the ground, and burrow depth (Table 2).

Regarding foraging burrows found in the different environments studied (road and shrubby grassland), there were recorded 144 burrows in the road and 53 burrows in the shrubby grassland. The mean density of foraging burrows for 21 points sampled on the roads and shrubby grassland were 6.86 (standard error (SE) \pm $1.53)$ and $2.52(\mathrm{SE} \pm 0.642)$, respectively. The results of the ANOVA, $p<0.05$, and Tukey test, $p<0.05$, demonstrate a significant difference between the mean densities of foraging burrows in the said environments. This shows that the shrubby grassland environment of the EEI has an estimated density of 114 foraging burrows/ ha in areas with vegetation (shrubby grassland) and 42 in areas without vegetation (roads).

\section{Discussion}

The density of armadillo burrows in the shrubby grassland area probably was considered high for both species in the EEI. However, even though he knew the importance of comparison of densities with similar studies to have parameter settings, it did not find any information about it in the literature. The density of burrows of $E$. sexcinctus was twice higher than that registered to $C$. unicinctus. Lima Borges and Thomas (2004) report, that $E$. sexcinctus can make agglomerates burrows in open areas. (2004) report that E. sexcinctus can make agglomerate burrows in open areas. Additionally, Redford and Wetzel (1985) cite that armadillo species can reuse old burrows. Some species of the genus Cabassous change new burrows all night (Encarnação 1987; McDonough and Loughry 2003). However, there is no information about the theme to C. unicinctus. Based on the information that has to home range, which is up to 101.06 ha for C. unicinctus and up to 958.0 for E. sexcinctus (Encarnação 1987), it is believed that these species dig various burrows during their lifetime. This probably makes $E$. sexcinctus have to dig more burrows.

Table 1 Number and morphometry of burrows of C. unicinctus and E. sexcinctus (mean \pm standard error and minimum and maximum measurements) at Estação Ecológica de Itirapina

\begin{tabular}{llllll}
\hline Dasypodidae & \multicolumn{5}{l}{ Morphometric variables } \\
\cline { 2 - 6 } Species & $N$ & Depth $(\mathrm{cm})$ & Ratio $(\mathrm{cm})$ & Perimeter $(\mathrm{cm})$ & Angle $\left(^{\circ}\right)$ \\
\hline${\text { C. } \text { unicinctus }^{\mathrm{a}}}^{\mathrm{N}}$ & 80 & $37.50 \pm 0.84(18-60)$ & $1.01 \pm 0.01(0.9-1.0)$ & $38.40 \pm 0.36(32.9-39.8)$ & $65.00 \pm 1.22(45-90)$ \\
E. sexcinctus $^{\mathrm{b}}$ & 100 & $65.36 \pm 2.7(18-150)$ & $1.19 \pm 0.01(0.9-1.4)$ & $59.32 \pm 0.82(38.6-75.3)$ & $54.56 \pm 0.97(30-90)$ \\
\hline
\end{tabular}

Letters $\mathrm{a}$ and $\mathrm{b}$ indicate the significant difference between the burrows of the species for all variables 


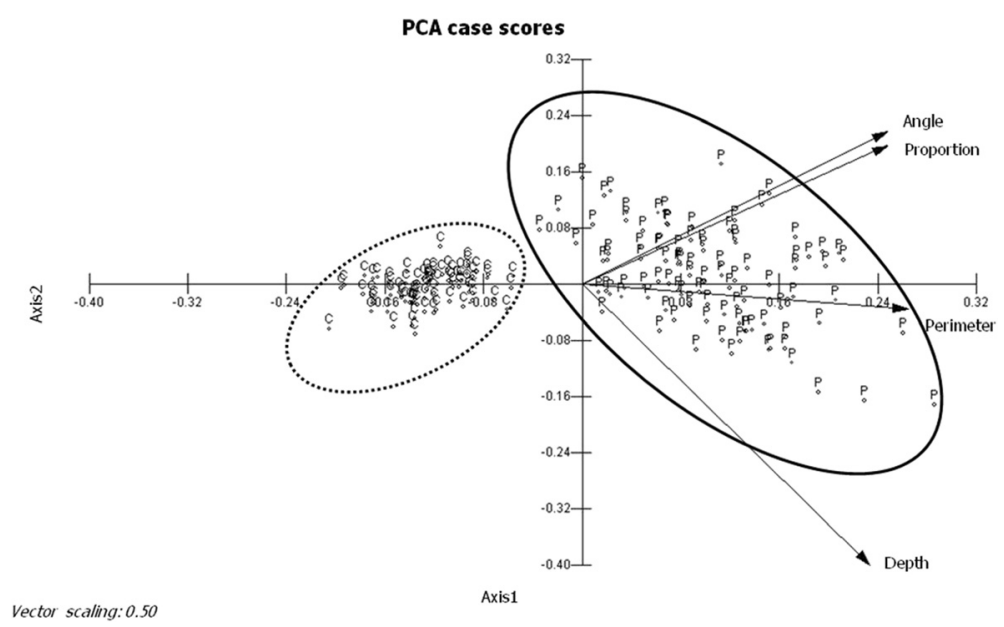

Fig. 2 Principal Components Analysis of the burrows of $C$. unicinctus $(C)$ and E. sexcinctus $(P)$ in the Estação Ecológica de Itirapina

The burrows excavated by armadillos, which are used for sleeping, nesting, escaping predators, thermoregulation, or creating an insect reservoir, are dug in welldrained soils or into ant and termite mounds (McDonough and Loughry 2003, 2008).

Nonetheless, in the same study area, Bonato et al. (2008) obtained inverse values regarding the density of individual armadillos, estimated using a mark-recapture method, showing 0.26 individuals/ha for C. unicinctus and 0.14 individuals/ha for E. sexcinctus. Probably, the higher density of $E$. sexcinctus burrows is related to the behavior of digging more burrows compared to C. unicinctus, and not with its abundance (density), which could be explained by the fact that the latter armadillo species is more fossorial (Wetzel 1980). When it is assumed that $C$. unicinctus is more fossorial than E. sexcinctus, it is believed that this can spend longer periods of time in the subsurface and therefore produces less burrows. This is possibly explained by its anatomic difference. The relative development of the olecranon process is interpreted as an improvement of the mechanical advantage of the triceps muscle, the forearm extensor. C. unicinctus has a better anatomical development than E. sexcinctus (Vizcaíno et al.

Table 2 Comparison of values of the Principal Components Analysis for the variables (depth, angle, ratio, and perimeter) of the burrows of armadillos C. unicinctus and E. sexcinctus in the Estação Ecológica de Itirapina

\begin{tabular}{lcc}
\hline Variables & Axis 1 & Axis 2 \\
\hline Percentage & 69.81 & 13.37 \\
Depth $^{4}$ & 0.47 & -0.80 \\
Ratio $^{2}$ & 0.49 & -0.39 \\
Perimeter $^{1}$ & 0.53 & -0.07 \\
Angle $^{3}$ & 0.49 & 0.43 \\
\hline
\end{tabular}

Numbering from 1 to 4 indicates the order of influence of the variable in separating the burrows, $1>$ influence $4<$ influence
1999). But differences in morphological characteristics (Marinho-Filho et al. 1998; Medri et al. 2011) and feed between the two species should not be forgotten (Dalponte and Tavares-Filho 2004; Anacleto 2007; Bonato et al. 2008; Vaz et al. 2012).

The differences in depth, ratio, and perimeter also can be explained by anatomical and morphological characteristics of each species. C. unicinctus measures $34-44 \mathrm{~cm}$, with a tail of 16.5-20 cm (Eisenberg and Redford 1999; Nowak 1999; Hayssen 2014), and weighs between 2.2 and $4.8 \mathrm{~kg}$ when adult (da Merrit 1985; Redford 1994; Hayssen 2014). The carapace has 10 to 13 movable bands (Emmons and Feer 1997). The tail is leather (devoid of corneal plates), but the main feature is the strong claws (Marinho-Filho et al. 1998), with the largest claw being sickle shaped (Medri et al. 2011). In contrast, E. sexcinctus is larger, measuring $46-54 \mathrm{~cm}$ in rostrum-anal length, with a tail of $22.2 \mathrm{~cm}$ on average, and weighs around 3 to $6 \mathrm{~kg}$ (Redford and Wetzel 1985; Eisenberg and Redford 1999; Anacleto et al. 2006). The head of this kind is conical and flat on top. The carapace is semicircular in shape, with 6 to 8 movable bands and long hair. The tail is long and protected by corneal rings (Silva 1994). However, these same characteristics are also overlapped, which can be explained by the juxtaposition of the morphological measurements of these species.

Minimum burrow depth may be controlled primarily by factors other than the short-term energy cost of burrowing. Shallow tunnels in sandy soil readily cave in as the soil dries out. Shallow tunnels dry out more quickly, are subject to greater temperature fluctuations, and are easily destroyed by any large animals stepping on the surface above them (Vleck 1981). Thinking about the ratio and perimeter of the burrows, the energy cost of burrowing is directly proportional to the mass of soil removed. Thus, cost of burrowing is roughly proportional to the square 
root of body mass (Vleck 1981). This reflects a lower energetic cost of C. unicinctus in relation to E. sexcinctus to remain in the subsoil.

The difference observed in the angle of excavation of the burrows shows that, in general, E. sexcinctus prefers to dig burrows at a lesser angle of inclination than $C$. unicinctus, whose burrows are more perpendicular to the soil. This can once again be explained by the differences in anatomical and morphological structure of forelimbs and claws of the species. C. unicinctus has short forelimbs and particularly well-developed, strong, curved claws (Marinho-Filho et al. 1998), with the largest of these claws shaped like a sickle (Medri et al. 2011), while E. sexcinctus has members and less robust muscles and is prone to digging (Vizcaíno et al. 1999). The forelimbs as hind limbs have five fingers, with claws, the second finger being the most developed (Pocock 1924).

Seabloom et al. (2000), using Thomomys bottae as a model, found that the cost of tunnel construction is independent of hill slope angle and that the costs of shearing soil and pushing soil horizontally through the tunnels were three orders of magnitude greater than the costs of lifting the soil against the force of gravity. This fact strengthens the increased ease of C. unicinctus to remain in the subsoil due to its lower mass corporeal. This provides excavation at an almost straight angle, thus decreasing energy expenditure. Thus, the optimum angle for constructing a burrow that involves the lowest energy cost is perpendicular to the surface (Arteaga 2004), especially in sandy soil (Vleck 1981). However, for C. unicinctus that dig their burrows in shallow angle seems to be more associated with their anatomy than the soil type. But this needs to be better studied.

The PCA showed a clear distinction between the burrows of these two species of armadillo. Generally, all the variables had some influence on differentiating the burrows, but the perimeter was a determining factor for distinguishing them. According to Carter and Encarnação (1983), Redford and Wetzel (1985), and Parera (2002), E. sexcinctus typically constructs burrows with an "inverted U"-shaped opening. The burrows of C. unicinctus, on the other hand, present a circular shape, since they dig while twisting their body in helical movements (Carter and Encarnação 1983). The difference in the burrows between $C$. unicinctus and E. sexcinctus is evident and easily identified in the field by the format of the burrow opening (Fig. 1). However, the observer does require some degree of experience. Thus, when the observer is inexperienced, calculating the perimeter can assist in identifying whether the burrow belongs to $C$. unicinctus or E. sexcinctus. According to Srbek-Araujo et al. (2009) and Ceresoli and Fernandez-Duque (2012), the most species that dig their own burrows, produce of specific size and shape.
The high density of burrows found in the road area in this study could be explained by the fact that armadillos also use this environment to feed. Redford (1985) mentioned that the shallower burrows of armadillos are commonly for foraging. It seems unlikely that shallow burrows, those with a depth of less than $70 \mathrm{~cm}$, would provide shelter for these animals because they would make it easier to be caught by predators (Tozetti and Granzinolli 2000). Even though the road and adjacent areas are frequently disturbed and are often hostile environments for many species of wildlife, they can provide attractive features, including shelter, food, or nesting sites and could even facilitate the displacement of some species (Seiler 2001).

Additionally, according to Taraborelli et al. (2009), predation risk would be related to vegetation structure. For behavioral patterns of digging burrows in an area, beneath the cover provided by trees, shrubs, and herbaceous plants, shrubs and trees would afford vertical protection from raptors, but herbaceous plants would obstruct visual detection of terrestrial mammalian predators and of the shadow of raptors on the ground (Taraborelli et al. 2008). EEI has potential predators of C. unicinctus and E. sexcinctus, and these are the following terrestrial carnivores: Leopardus pardalis, Puma concolor, Procyon cancrivorous, Cerdocyon thous, and Chrysocyon brachyurus (Trovati 2009), with Harpyhaliaetus coronatus being the only possible raptor (Trovati 2009; Motta-Junior et al. 2008). This strengthens the idea that the preference of armadillos feed on the road in the study area is related to lower predation risk.

\section{Conclusions}

It can be concluded that this study provides information on relatively common species of armadillos in the Cerrado biome and which are usually forgotten. Thus, further studies are needed with fossorial mammals in the neotropical region, as these are possibly keystone species, given that their holes not only are influenced by biotic and abiotic factors but also act on these factors.

\section{Competing interests}

The author declares that he has no competing interests.

\section{Acknowledgements}

The author would like to thank the São Paulo Forestry Institute (Instituto Florestal), in particular, the Itirapina base for authorizing research in the area. He would also like to thank the friends of the Ecology Field Course of the Institute of Biosciences of the University of São Paulo (IB-USP), especially Hipólito Paulino for the friendship and helpful suggestion in this manuscript.

Received: 9 May 2015 Accepted: 24 November 2015 Published online: 10 December 2015 


\section{References}

Abba AM, Superina M (2010) The 2009/2010 armadillo red list assessment Edentata 11:135-184

Abba AM, Vizcaíno SF, Cassini MH (2007) Effects of land use on the distribution of three species of armadillos in the Argentinean Pampas. J Mammal 88:502-507

Anacleto TC d S (2007) Food habits of four armadillo species in the Cerrado area, Mato Grosso, Brazil. Zool Stud 46:529-537

Anacleto TC d S, Diniz Filho JAF (2008) Efeitos da alteração antropica do cerrado sobre a comunidade de tatus (Mammalia, Cingulata, Dasypodidae). In: Reis NL, Peracchi AL, Santos GASD (eds) Ecologia de mamíferos. Technical Books, Londrina, pp 55-67

Anacleto TC d S, Diniz-Filho JAF, Vital MVC (2006) Estimating potential geographic ranges of armadillos (Xenarthra, Dasypodidae) in Brazil under niche-based models. Mammalia 70:202-213

Arteaga MC (2004) Efeito da estrutura do ambiente e da fragmentação florestal no uso do habitat por tatus (Xenarthra: Dasypodidae) na Amazônia Central. Dissertation, Instituto Nacional de Pesquisa da Amazônia

Arteaga MC, Venticique EM (2008) Influence of topography on the location and density of armadillo burrows (Dasypodidae: Xenarthra in the central Amazon, Brazil. Mammal Biol 73:262-266

Arteaga MC, Venticique EM (2012) Effects of change in primary forest cover on armadillo (Cingulata, Mammalia) burrow use in the Central Amazon. Rev Mex Biodiv 83:177-183

Bagagli E, Bosco SM, Barbosa FH, Montenegro MR (2004) Importância do tatu na paracoccidioidomicose. In: Uieda W, Paleari LM (eds) Flora e Fauna - um dossiê ambiental. Editora UNESP, São Paulo, pp 149-160

Becker M, Dalponte JC (1999) Rastros de mamíferos silvestres brasileiros: um guia de campo. UNB/IBAMA, Brasília

Bonato V, Martins EG, Machado G, Da-Silva CQ, Dos Reis RF (2008) Ecology of the armadillos Cabassous unicinctus and Euphractus sexcinctus (Cingulata: Dasypodidae) in a Brazilian Cerrado. J Mammal 89:168-174

Brasileiro CA, Sawaya RJ, Kiefer MC, Martins M (2005) Amphibians of an open Cerrado fragment in Southeastern Brazil. Biota Neotrop 5, http://www. biotaneotropica.org.br/v5n2/pt/abstract?article+BN00405022005 Accessed 24 Ago 2015

Brito BA, Trovati RG, Prada M (2001) Levantamento de mamíferos terrestres de médio e grande porte na área de influência da UHE Luís Eduardo Magalhães, região central do Tocantins. Humanitas 03:07-20

Carter TS, Encarnação CD (1983) Characteristics and use of burrows by four species of armadillos in Brazil. J Mammal 64:103-108

Ceresoli N, Fernandez-Duque EF (2012) Size and orientation of giant armadillo burrow entrances (Priodontes maximus) in western Formoso province, Argentina. Edentata 13:66-68

da Merrit J (1985) Naked-tailed armadillos, Cabassous sp. In: Montgomery GG (ed) The evolution and ecology of armadillos, sloths, and vermilinguas. Smithsonian Institution Press, Washington, pp 389-391

Dalponte JC, Tavares-Filho JA (2004) Diet of the yellow armadillo, Euphractus sexcinctus, in South-Central Brazil. Edentata 6:37-41

Eisenberg JF, Redford KN (1999) Mammals of the neotropics: Ecuador, Peru, Bolivia, Brasil. University of Chicago Press, Chicago

Emmons LH, Feer F (1997) Neotropical rainforest mammals: a field guide, 2nd edn. University of Chicago Press, Chicago

Encarnação CD (1987) Contribuição à ecologia dos tatus (Xenarthra, Dasypodidae) da Serra da Canastra, Minas Gerais. Universidade Federal do Rio de Janeiro, Dissertation

Fonseca GAB, Herrmann G, Leite YLR, Mittermeier RA, Rylands AB, Pantton JL (1996) Lista anotada de mamíferos do Brasil. Conserv Biol (Occasional papers) 4:1-38

Hayssen V (2014) Cabassous unicinctus (Cingulata: Dasypodidae). Mamm Species $46: 16-23$

Koneval TO (2003) Comparative hindlimb anatomy and fossoriality of three armadillos: Dasypus novemcinctus, Tolypeutes matacus, and Chaetophractus vellerosus (Mammalia, Xenarthra, Cingulata, Dasypodidae). PhD Dissertations, University of Massachusetts

Kovach WL (1999) MVSP — a multi-variate statistical pack-age for windows, ver. 3. 1. Kovach computing Services, Penthraeth

Lima Borges SPA (2004) Tomás WM. Guia de rastros e outros vestígios de mamíferos do Pantanal Embrapa Pantanal, Corumbá

Marinho-Filho J, Rodrigues FHG, Guimarães MM, Reis ML (1998) Os mamíferos da Estação Ecológica de Águas Emendadas, Planaltina, DF. In: Marinho-Filho J, Rodrigues FHG, Guimarães MM (eds) Vertebrados da Estação Ecológica de
Águas Emendadas: história natural e ecologia em um fragmento de cerrado do Brasil central. Universidade de Brasília, Brasília, pp 34-63

Marinho-Filho J, Rodrigues FHG, Juarez KM (2002) The cerrado mammals: diversity, ecology and natural history. In: Oliveira PS, Marquis RJ (eds) The cerrados of Brazil: ecology and natural history of neotropical savanna. Columbia University Press, New York, pp 287-305

McDonough CM, Loughry WJ (2003) Armadillos (Dasypodidae). In: Hutchins M (ed) Grzimek's animal life encyclopedia, vol 13. Gale Group, Farmington Hills, pp 181-192

McDonough CM, Loughry WJ (2008) Behavioral ecology of armadillos. In: Vizcaíno SF, Loughry WJ (eds) The biology of the Xenartha. University of Florida, Gainesville, pp 281-293

McDonough CM, Delaney MA, Le PQ, Balckmore MS, Loughry WJ (2000) Burrow characteristics and habitat associations of armadillos in Brazil and the United States of America. Rev Biol Trop 48:1009-1020

Medri IM, Mourão G, Rodrigues FHG (2011) Ordem Xenarthra. In: Reis NR, Paracchi AL, Pedro WA, Lima IP (eds) Mamíferos do Brasil (2ed). Nélio Roberto dos Reis, Londrina, pp 75-90

Minitab 17.0. (2015) Statistical software. State College, CD-ROM

Motta-Junior JC, Granzinolli MAM, Develey PF (2008) Birds of the Estação Ecológica de Itirapina, State of São Paulo, Brazil. Biota Neotrop 8, http://www. biotaneotropica.org.br/v8n3/en/abstract?inventory+bn00308032008. Accessed 24 Ago 2015

Nowak RM (1999) Walker's mammals of the world, 6th edn. The John Hopkins University Press, Baltimore

Parera AF (2002) Los mamíferos de la Argentina y la región austral de Sudamérica. Editorial El Ateneo, Buenos Aires

Paulino-Neto HF (2014) Polinização e biologia reprodutiva de Araticum-liso (Annona coriacea Mart:: Annonaceae) em uma área de cerrado paulista: implicações para fruticultura. Rev Bras Frut 36:132-140

Pocock, RIFRS (1924) The External Characters of the South American Edentates. Proc Zool Soc Lond 94:983-1031.

Redford KH (1985) Food habits of armadillos (Xenarthra: Dasypodidae). In: Montgomery GG (ed) The evolution and ecology of armadillos, sloths, and vermilinguas. Smithsonian Institution Press, Washington, pp 429-437

Redford KH (1994) The edentates of Cerrado. Edentata 1:4-10

Redford KH, Wetzel RM (1985) Euphractus sexcinctus. Mamm Species 252:1-4

Schaller GB (1983) Mammals and their biomass on Brazilian ranch. Arq Zool $31: 1-36$

Seabloom EW, Reichman OJ, Gabet EJ (2000) The effect of hillslope angle on pocket gopher (Thomomys bottae) burrow geometry. Oecologia 125:26-34

Seiler A (2001) Ecological effects of roads: a review. Grimsö Wildlife Research Station, Dept. of Conservation Biology, University of Agricultural Sciences, S-730 91 Riddarhyttan, Sweden

Silva F (1994) Mamíferos silvestres do Rio Grande do Sul, 2nd edn. Fundação Zoobotânica do Rio Grande do Sul, Porto Alegre

Srbek-Araujo AC, Scoss LM, Hirsch A, Chiarello AG (2009) Records of the giantarmadillo Priodontes maximus (Cingulata: Dasypodidae) in the Atlantic forest: are Minas Gerais and Espírito Santo the strongholds of the species. Zoologia 26:461-468

Superina M, Pagnutti N, Abba AM (2014) What do we know about armadillos? An analysis of four centuries of knowledge about a group of South American mammals, with emphasis on their conservation. Mammal Rev 44:69-80

Taraborelli P, Moreno P, Srur AM, Sandobal AJ, Martinez MG, Giannoni S (2008) Different antipredator responses by Microcavia australis (Rodentia, Hystricognate, Caviidae) under predation risk. Behaviour 145:829-842

Taraborelli P, Borruel N, Sandobal AJ, Giannoni S (2009) Influence of biotic and abiotic factors on the structure of burrows of the cave, to see a more ecological approach. Mastozool Neotrop 16:411-421

Tozetti AM, Granzinolli MAM (2000) É possível determinar diferentes espécies de tatu a partir de suas tocas? In: Martins MRC, Mantovani W, Metzger JP (eds) Livro da disciplina de Ecologia de Campo. Universidade de São Paulo, São Paulo, pp 123-129

Trovati RG (2009) Mamíferos escavadores (Dasypodidae e Echimyidae) do cerrado da região de Itirapina e seu papel em comunidades de vertebrados terrestres, PhD Dissertation, "Luiz de Queiroz"College of Agriculture/University of São Paulo

Trovati RG, Munerato MS (2013) Occurrence record of Sus scrofa Linnaeus, 1758 (Mammalia: Artiodactyla) at Estação Ecológica de Itirapina, São Paulo state, Brazil. Check List 9:136-138 
Vaz VC, Santori RT, Jansen AM, Delciellos AC, D'Andrea PC (2012) Notes on food habits of armadillos (Cingulata, Dasypodidae) and anteaters (Pilosa, Myrmecophagidae) at Serra da Capivara National Park (Piauí State, Brazil). Edentata 13:84-89

Vizcaíno SF, Fariña RA, Mazzetta GV (1999) Ulnar dimensions and fossoriality in armadillos. Acta Theriol 44:309-320

Vleck D (1981) Burrow structure and foraging costs in the fossorial rodent, Thomomys bottae. Oecologia 49:391-396

Wetzel RM (1980) Revision of the naked-tailed armadillo genus Cabassous McMutrie. Ann Carnegie Mus 49:323-357

Submit your manuscript to a SpringerOpen ${ }^{\circ}$ journal and benefit from:

- Convenient online submission

- Rigorous peer review

- Immediate publication on acceptance

- Open access: articles freely available online

- High visibility within the field

- Retaining the copyright to your article

Submit your next manuscript at $\gg$ springeropen.com 